This item was submitted to Loughborough's Research Repository by the author.

Items in Figshare are protected by copyright, with all rights reserved, unless otherwise indicated.

\title{
Utopia or elsewhere: queer modernities in small town West Bengal
}

PLEASE CITE THE PUBLISHED VERSION

https://www.palgrave.com/gb/book/9783319476223

\section{PUBLISHER}

Palgrave Macmillan @ The Authors

\section{VERSION}

AM (Accepted Manuscript)

\section{PUBLISHER STATEMENT}

This book chapter was published in the book Urban Utopias: Excess and Expulsion in Neoliberal South Asia by Palgrave Macmillan. The definitive published version is available at https://www.palgrave.com/gb/book/9783319476223.

\section{LICENCE}

CC BY-NC-ND 4.0

\section{REPOSITORY RECORD}

Boyce, Paul, and Rohit Dasgupta. 2017. "Utopia or Elsewhere: Queer Modernities in Small Town West Bengal”. figshare. https://hdl.handle.net/2134/23786. 


\section{Chapter 11}

\section{Utopia or Elsewhere}

Queer Modernities in Small Town West Bengal

Paul Boyce and Rohit K Dasgupta

\section{Indian Utopias: Limits and Excess}

Like all good contemporary scholars, we began our musings for the composition of the present chapter with a Google search - testing the current media environment for what it might generate in terms of unexpected information or signifiers. Our favored search term 'India Utopias' yielded some expected leads - links to information about Auroville, the website of a data-services provider etc. Each of these options signify a spectrum of utopian imaginary concerning contemporary India, the former perhaps located in the ideation of a retreat from modernity, the latter firmly anchored in techno-commerce. Uncannily, in terms of the themes of the chapter, we also found ourselves directed to the website 'UtopiaAsia.com,' which offers travel advice to 'Lesbian, Gay, Bisexual and Transgender (LGBT)' tourists planning to travel in the Asia region. The advice on offer includes information on places to stay and visit, along with ready reckoners pertaining to law and culture in different countries. The travel guidance for India offers information that outlines a particular sociocultural-legal scenario. In particular, the website informs that in India:

Gays are reluctant to be stereotyped in the public mind as being effeminate or transgender, and non-conformity is one of the biggest fears for self-identified LGBT. Most challenging to change will be the unique relationship between Indian sons and mothers. Women largely secure their social status by raising their sons to be gods - gods who worship their mothers. While daughters are farmed off to serve their husband's family, Mum is largely focused on getting her boy married. Once married, he has only to produce a male heir and then he is free to resume his natural inclinations. The pressure to please Mum is acute and most homosexuals in India will eventually succumb, whether they have any interest in the opposite sex or not. Thus, this karmic tragedy continues to repeat until the day mothers prioritize their gay sons' happiness or sons get the courage to just say 
"no." Yet there is hope. Rallying to their children's side during the 2012 Supreme Court review of the Delhi High Court's overturn of the buggery law, Indian television viewers got to hear some radical words from a large group of parent's who chastised opponents - "how dare you say the ruling is anti-family! We are the families." (Utopia-Asia, n.p)

The Indian socio-cultural situation is described on the Utopia Asia web-site as one in which 'change' in respect of an assumed aspiration for an 'out' and self-identified same-sex desiring and practicing subject might be hard to bring about because of a particularly static psychocultural circumstance. In this version of South Asian culture family and kinship is not only analytically central but also located in an alternative to an oedipal psycho-drama in which the mother-son relation prevails over and above a narrative of mother-son love being interceded by the son's realization of a mother-father eroticism (Nandy 2009).

The archetypical nature of this psychoanalytic framing of sexuality offers a version of culture that might be imagined as both fixed and excessive; fixed in the sense that it is portrayed as psycho-dynamically intrinsic within a narrative of cultural particularity, but excessive in that the affective connection between mother and son is portrayed as overly enduring and problematic. This erotic attachment is seen to intercede into other desires, whereby the son, on marriage, might produce a child, after bearing which he might then turn back to his 'natural inclinations,' as Utopia-Asia would have us believe. In this sense the South Asian male is portrayed as perhaps always already a queer subject, whose attachment to the mother accents insinuations of inclinations toward same-sex erotic attachment (Osella and Osella 2006).

Against this background, in this chapter, which is based on ethnographic research conducted in small towns in West Bengal, India', we are interested in the symbiosis of intimate and everyday lives with wider socio-economic processes among people of same-sex desiring experience. We focus on how such processes connect to aspirations for intimate relationships, both same-sex sexual relations and connections to community and kin (Boyce 2013). Our particular focus is to move away from the growing work on same sex desires in the larger more cosmopolitan sites of urban India (Dasgupta, 2014; Dasgupta, 2015; Dasgupta, forthcoming; Shahani, 2008) and to instead examine the everyday tensions and practices of 
sociality and same-sex intimacy in peri-urban Bengal as such life-worlds may relate to ideas of urban self-realization or otherwise. In turn this work engenders wider questions about queer utopian imaginaries and ways of imagining relations between 'queer subjects' and others in the wider context of contemporary India.

We especially take up concerns around contemporary 'liveable lives' (Banerjea, Browne, Bakshi and Ghosh, 2016) and social visibility for same-sex desiring subjects. A prevailing narrative of queer life-trajectories, in India and elsewhere, has been oriented around escape from small towns to larger and potentially more anonymous cities (Barton, 2013, Weston 1995), where a sense of freedom from heteronormative social mores and familial obligations may be imagined and experienced. Migration to big cities has been imagined both geographically and temporally - cosmopolitan centers offering not only anonymity and potential social venues for queer subjects, but also a seemingly more modern outlook and attitude wherein same-sex desires might more readily find expression. Engebretsen (2012: 194) argues that sexual marginality 'as identity, discourse and sub cultural community' provides an ideal place for interrogating issues of anthropological methodology and ethics and such research provides the means to re-evaluate how ethnographic knowledge of sexual cultures is produce.

In this context we consider the narratives of the subjects presented in this chapter as potentially undergirded by themes of excess, which trouble urban-oriented queer utopian narratives. We explore the themes of queer utopia as an embodiment and spatiality that might exceed containment within the hyper social-visibility of small towns (where many people know one another), but also in terms of big cities as excessive domains - big enough to contain social difference and diversity. We also seek to problematize the spatial-temporal and psychodynamic underpinnings of such narratives to open up questions pertaining to where, when and in what terms same-sex sexual life-worlds might be realized. Considering these themes as they relate to the aspirations of some of our small-town interlocutors in West Bengal we are also interested in how such migratory narratives might have led to an invisibility of same sex experience within local and regional histories - small towns, and their close natal ties, being cast as sites of origination and departure in many mainstream queer narratives as opposed to the actual mise en scene of queer life-worlds. 


\section{Space, Future, Child}

To preface the ethnographic context of our analysis it us useful to recall that spatial imaging has been intrinsic to utopian thought. Oscar Wilde's oft-cited cartographic metaphor for the imagining of a world without utopias points to a seeming romantic validation of utopian ideals as connected to progress (and which might be read in conjunction with ideas that conflate queer futurities with urban locales - a kind of 'elsewhere' for our small town informants):

\footnotetext{
A map of the world that does not include Utopia is not worth even glancing at, for it leaves out the one country at which Humanity is always landing. And when Humanity lands there, it looks out, and, seeing a better country, sets sail. Progress is the realisation of Utopias' (Wilde, 1891: n.p).
}

This is a vision wherein humanity might be achieved via a version of socialism that attaches a view of fully realized individuals to aesthetic ideals - humanity liberated form mundane labor and poverty to pursue arts and leisure. For Wilde utopian imaginary was connected to artistic humanism in these terms. He outlined an ideal of progress not in the sense of restless socioeconomic advancement but out of a commitment to an aesthetic ideal. This schema played with prevailing ideas of Wilde's era, evoking progress but purposefully locating that outside logics of capitalist, abstract utopianism.

Utopian thought and politics has been critiqued for abstraction, by Ernst Bloch, or for example, for presenting an idealized form of escape; a projective dream engendered out of capitalism and its estrangements and discontent, rather than actual political goals (Bloch, 1986). Predating Bloch, but in sympathetic terms, Wilde's utopian writing was founded on a critique of abstract utopia too and on a concrete principle of change. He sees change as a condition of human existence, where nothing is permanent. It is in the recognition of this that we might see in Wilde ideals of futurity as always already located in the reality of the present, and its discontents. His ideal of utopia might be said to signify that to which we may aspire but never realize. Arriving at utopia, in any present moment, is to experience a realization that in its own becoming emerges as mundane. Utopia, in these terms, always shimmers on the horizon; indeed, it may be defined as the horizon - a phantasm, always elsewhere. 
The cartographic element of Wilde's utopia connects to Thomas More's originary Utopian narrative. For More, Utopia was imagined in geographic terms - an imaginary island that by its nature might never be arrived at, and which upon arrival might anyway not live up to its ideals. This spatial-temporal imagining provides a metaphorical resonance, linking queer lifeworld perspectives, and theorization of utopia and excess (for example in India or elsewhere).

This schema reverses the logic of capitalist individualism to conceive of capital as that that quashes individual potentiality against the liberatory potential of socialism - and of course the lineages and contemporary connections are evident (also see Eagleton, 2011). But this is a logic that might now read as flawed against the background of contemporary aspirational ideals, which within the increasingly hegemonic flow of neo-liberal market ideals anchor individual realization to the acquisition of prosperity in other terms - to market imaginaries and forces; the attainment of dreams through consumption.

If utopian ideals are a necessary or inexorable effect of the inevitability of discontent in the present - the ephemera of dissatisfaction - they might pertain especially to queer imaginaries. Queer perspectives on futurity have accented the unrealizable conditions for queer life-worlds in the present. A queer utopian view might emerge in these terms as an affective attachment to a better life, even if that life remains out of reach, this perhaps being the condition of its projected romantic existence. Jose Esteban Munoz' polemic on queer utopianism, as a critical instance, might be conceived after this kind of futurist perspective; an evocation of political and life-world conditions yet to come because to-date adequate conditions for the realization of queer subjects and life-worlds do not exist. In these terms the queer (utopian) subject might be figured as excessive because necessarily existing beyond any present time-space possibilities, being staked in futures and in other places (modernity/big cities). Such dislocation of the subject, temporally and geographically, links queer imaginaries to the Indian utopian problematic of the present volume - as figures of perhaps phantasmatic futurity, even embodying pressing, contemporary socio-political circumstances. This links to ways in which Munoz utilized Bloch's thought to evoke an idea of queer futurity out of antirelational modes of engaging to position a politics of longing that locates in an awareness of historical struggles for recognition, but which might emerge out of the aesthetic actions of the present. 
A more nihilistic version of such a utopian narrative queries the idea of the future and the present practices in which it might seek anchorage for queer subjects. Lee Edelmen points to the normativity or futurist imaginaries; their location in tropes of aspirational legitimacy and recognition in the present. These orient toward a future that Edleman repudiates. The child (and law) signify the kind of future against which Edelman rails, as signifiers that carry with them forms of projected legitimacy. He famously rails;

Fuck the social order and the Child in whose name we're collectively terrorized; fuck Annie; fuck the waif from Les Mis; fuck the poor, innocent kid on the Net; fuck Laws both with capital ls and small; fuck the whole network of Symbolic relations and the future that serves as its prop. (Edelman, 2004: 29)

For Edelman queer utopianism is located in a future orientation that is not really queer because a truly queer position might not be realized via heteronormative aspirational tropes. This is not to suggest that reproductive futures might not have been central to the queer movement, in India or elsewhere. However, it is to stress the forms of political traction that have emerged around the figure of the queer son or daughter as signifier for recognition - the queer child as located within the normative terrain of socially/legislatively legitimate kinship as opposed to performing as singular figure at the margins of relatedness. Relatedly, an excessively legally focused strategy for the realization of queer legitimacies has also been queried in the period after the reinstatement of IPC 377 by the Indian Supreme Court raising questions about why the contemporary queer subject ought to orient toward the state and/or law as the locus for legitimate recognition - in the future (Nagar and Dasgupta, 2015; Narrain and Gupta, 2011). This too opens questions about the direction of queer politics and activism in India and its oft orientations toward cosmopolitan imaginaries, and by association in the relation to the city - as urban political sites in which the queer subject might be at once realized but lost.

\section{The City or the Self?}

Siliguri and Barasat are small towns in the north and middle of West Bengal respectively. Siliguri, is the second largest town in West Bengal, with a population of 513264 (census data, 2011). Siliguri is regionally significant for attracting new investment from out of the 
State. This is partly because of the city's strategic location near to a range of internal and cross-national borders. Hence, investment in the region has increased somewhat since the last State elections in 2011. Consequently, while in regional terms Siliguri is not so small, on a national scale the city certainly cannot be cast as a large metropolitan centre. Barasat, on the other hand, is a small town just on the outskirts of Kolkata in the North 24 Parganas district. It relies mostly on the sale of agricultural products with cotton weaving being a major industry. Most of the residents work in Kolkata due to the towns close proximity and transport connections.

For Aveek leaving Kolkata was very much about leaving his father. He had been living in Siliguri for about three years since 2012, at the time when field research for the present paper was conducted - and indeed Aveek has continued to live in the city since that time. Aveek felt that he had had a sense of himself as same-sex desiring since he was a child - not a realisation he could put an age to, but just an always already present sense of sexual difference. Aveek had done well in his school studies in Kolkata and after graduation had passed exams to study medicine. Yet he had felt stifled too by the trajectory that was opening up before him - a life mapped out across projected pathways to achievement and familial pride. Such aspirations resided in Aveek as somehow intolerable - a conformation to the role of successful son and so on that was unappealing in respect of what had felt like its looming normative constraints. Aveek reported this as an especially difficult and pivotal period in his life - one in which choices about the future transected directly with what were emerging with nascent imaginaries of what his life to come may be.

It was against this background that Aveek decided to leave home, to leave Kolkata; to alter the narrative he saw himself falling into and to open the trajectory that he wanted to claim for himself. He rejected medicine to study pharmacy, for which subject he had an offer to study in Siliguri. His decision provoked much consternation within his family - as a choice to study a less prestigious subject, with good but lesser prospects than a medical career per se. But for Aveek such a re-setting of his future horizons was intrinsic to the path he wanted to tread - to re-set the future against a set of normative aspirations that were closing in around him. The rejection of medicine for pharmacy; the move from Kolkata to Siliguri, the failure in terms of the narrative of successful son were intrinsic to the claiming of a queer life project. 
Aveek became involved in sexualities activism in Siliguri, as one of the activists associated with founding 'Neel Phool (Blue Flower)' - a support and political advocacy group for sexual and gender minority persons on in the North Bengal region. Against this background, what is perhaps so resonant in Aveek's story are its common trajectories and reversals. The father as figure of repressive authority acted as a reminder of familial oppression for Aveek a signifier in a narrative of self-realization against a perceived normative masculinity. In these terms a descriptions of a repressive situation (in his family, in Kolkata) was conceived of by Aveek as generative. The psychodrama mother-son dyad (Nandy, 2009) was not a strong feature of Aveek's story, or his usual account of himself. Rather, for him, his father loomed large as a figure to be turned away from. And this signified too the turning away from heterosexuality - and the locus or normative kinship. Orienting toward same-sex objects of desire (men in Aveek's case) meant treading the recursive narrative of rejection and repudiation. He did not confess his desires to his parents- rather he moves away, not only from his family and the city, but from the constraints of hetero-normative aspiration.

And for Aveek the smaller, admittedly growing and rapidly urbanizing town of Siliguri offered a potentiality that Kolkata did not. His story might be read as a claim to a future, but a repudiation of the future in other terms. The smaller town, where Aveek was admittedly an outsider, offered room to breathe in a way that Kolkata, as locus of familial expectations and normative expectations, did not. Siliguri was place where new horizons might open even within, or against the context of other imagined small-town limitations. And indeed Aveek's move there occurred at a time when narratives and possibilities of small-town queer activism in India were beginning to emerge and consolidate. This had been brought about by the work of activists in such locations who did not orient toward cosmopolitan queer activism, and in parallel by the at that time growth in funding for queer-type community-projects in regional towns in India, partly through investment in community-based rights and HIV prevention work by state governments (monies which since that time have contracted but which were instrumental in helping to support small town community projects for sexual and gender nonnormative peoples).

In evoking a small town/cosmopolitan contrast in respect of queer life-projects in West Bengal it is important to noted that Kolkata (as the main cosmopolitan context in the state) has no individual streets or neighborhoods identified as queer per se. Whilst spaces such as 
the Dhakuria Lake, the Nandan Complex and Minto Park are recognized as popular cruising grounds, there can be no straightforward mapping of such spaces as they are transient and constantly shifting with many former 'queer spaces' ceasing to exist or being transformed to other uses. However, despite this Kolkata attracts a large number of queer people from suburban and small towns scattered around West Bengal as a sort of utopic place which provides the temporary fulfilment of queer desires.

Naveen lives in Barasat, a suburban town just on the outskirts of Kolkata. As a nineteen-year old he was just about to start studying at a local college in his town. Naveen stayed with his parents in a small one storied house with two rooms. He shared a tiny rectangular bedroom with his parents, which had a large bed, a small alna, and a small desk stacked with his books, a tape recorder and a few audio cassettes. There were also a few posters of Hindu gods belonging to his mother displayed alongside two-newspaper cut out pictures of the popular Bollywood films Kaho Na Pyaar Hai (Say its love, 2000) and a bare chested Aamir Khan from Lagaan (2001). Naveen wore his hair slightly longer than his parents liked and often chose to wear worn-out jeans and a loose checked shirt revealing a small pendant of Baba Lokenath (a popular Hindu mystic in Bengal).

Naveen, who identified as gay, revealed his inability to be a part of the 'happening' gay scene in Kolkata owing to his location. When asked what urban scene he referred to he spoke of the freedom to live openly in a big city, one where he could get lost and no one would be there to question his life choices. He spoke at length about Park Street, which he had visited a year ago with some school friends, recollecting the bright lights and restaurants. He also recalled the 'handsome men' who all noticed him on the streets. Naveen's exaggerated imagining of a queer Kolkata evoked a certain kind of complexity. The city was imagined as a utopian, in a sense - locations where erotic and queer pleasures were etched on to the cityscape. But this perspective might be seen as far removed from reality.

A city like Kolkata is officially and unofficially zoned with certain neighborhoods designated for different purposes. For example, there exists a flower district, a fish market district and red light areas for those soliciting sex. However, there exists no specific 'queer zone'. Pat Califia (1994) in her landmark essay 'City of Desire' argues that separating the city into designated areas of specialization allows certain needs to be met but these are often 
superimposed upon other areas. Thus whilst Nandan Complex, a government run theatre and cinematic cultural center is a family oriented area during the day it rezones itself as a queer cruising ground to meet the excessive demand of its space.

Naveen attended the Queer Pride parade in Kolkata in 2009, which he explained opened his eyes to the queer political movement in the city. This was something different from what he had expected the 'utopic' queer scene in Kolkata to be. In his own words he found this 'excessive'. The constant media intrusion and the fear of getting recognized back in Barasat played on his mind. Rather than feeling the sense of freedom he described earlier he felt he had to hide his gayness. As Foucault (1990) has theorized when individuals imagine they are constantly under surveillance, they learn to regulate their behavior to conform to the majority behavior and not draw attention. Naveen's initial lamentation about the urban and anonymous freedom in Kolkata that was so nearby to his hometown of Barasat was dashed by this experience. It suddenly became that Kolkata and not Barasat was the panopticon he was so desperate to leave behind.

We met Sagar in 2011, who also lived in Barasat. He had finished a degree in English literature from a local college and had aspirations of moving out from his home which he shared with his parents. He was certain once had a job he would be able to move to Kolkata, as he called it the 'big gay city'. At the time we met Sagar was surviving on giving some English tuition to school students near his home and made just about enough to occasionally travel down to Kolkata. He also had a few friends in Barasat who identified as kothi. When enquired whether this kinship and forging of a community with other queer men had developed a sense of belonging to his hometown, Naveen was ambivalent:

They are okay. But they identify as kothi. They say I am kothi too but actually I am gay. I can speak English and do I look that girly to you? Have you heard of the Kolkata Pink Parties now? The city is becoming modern like Bombay.

It was interesting to see Sagar reject a sexual identity that he considered lower class (those who cannot speak English) and gendered (girlish, effeminate). Contemporary Indian sexual subjectivities are formed through a synergy of the global and local and as Naveen identifies sexual modernity is almost synonymous to building one's identity across a Western global 
template (gay not kothi). Naveen did not want to be 'regional', his aspiration was to be a part of the global urban gay identity based in Kolkata.

Sagar did try to attend the Kolkata Pink Party that was hosted at Roxy, a popular nightclub in the city but was rudely turned away. This incident led to a furor on social media much to the dismay of the organizers who were genuinely trying to create to a queer space in the city for socialising outside the NGO and cruising places. As Dasgupta (2014) has argued this incident marks the politics of recognition. Whilst the incident was viewed as a case of transphobic screening, much more insidiously it was related to reading class. Class is linked intrinsically to sexuality. Henderson (2013: 71) argues that 'recognition takes many forms, though some categories of social difference like sexuality have been more amenable to a positive politics of recognition, while others like class have been less so.' Sagar's recounting of this incident signals the fraught nature of recognition and belonging within the urban queer 'scene' in Kolkata.

In Sagar's words there is a sense of 'failure' that marks this incident. He kept saying 'ami parlam na' (I could not). This failure of course goes hand in hand with capitalism and Kolkata's neoliberal modernity. Neoliberalism requires that one live within a system of success (economic, romantic, etc) and assimilate within that culture. Sagar's inability to assimilate and rejection from the urban (classed) queer scene in Kolkata marks his queer failure (Halberstam, 2011).

Sagar does not embrace this failure as Halberstam (2011:24) describes it, as 'alternative ways of knowing and becoming that is not unduly optimistic'. The city according to Sagar remains replete with multiple possibilities, especially since the reading down of section 377 and effective decriminalization of homosexuality in 2009 yet it also signals the dismantling of the 'utopia' that he had created for himself.

Sagar as of 2013 has found a small clerical job in Belgharia, another northern suburb which is some distance away from Kolkata. He does not yet make the kind of money he needs to be able to live in Kolkata but he has made peace with his hometown and his kothi friends. Whilst suburban towns such as Barasat offer little space for anonymity and being able to pass marks much of the narrative; Sagar's life-world evokes the dichotomy that exists between the 
globalizing tendencies to assimilate to a global queer culture as experienced in large urban cities and the worlds inhabited by economically marginalized young men such as Naveen.

The idea of the big city as some kind of a utopia, one that contains the excesses of social and economic diversity is challenged through Naveen and Sagar's narrative. Small towns such as Barasat are not just sites of origination and departure, rather they can become an important site that stands in contrast to the predominantly urban neoliberal queer modernity that gets evoked as a marker of development.

\section{Room to Breathe}

Turning back to the website we began with in this essay and extending the elements of our ethnography in the wider field of media and representation what we encounter is a version of Indian sexual culture which is equally dealing with these issues of location, kinship and identity in an overtly simplistic form - this is both ironic and profound. The cultural stereotyping on display was sobering but revealing - signifying an attempt to convey something about Indian 'sexual culture' and values and locating this 'sexual culture' in tropes such as 'karmic cycles'. The website's information page attempts to analyze the contemporary situation in respect to same-sex desire in India via a seemingly culturally oriented account. The website posits the realization of improved futures of 'LGBT' subjects in India through a resolution and transgression of the mother-son psycho-drama intrinsic to the given narrative as a way of opening up to new kinds of (sexual) futures - represented as more modern and progressive.

At the same time however, this natal familial connectivity is also conceived of as the route to change. Utopia-Asia cites recent popular media interventions by families that were involved in advocating for their 'queer children' during the Supreme Court's review of the reading down of IPC 377 in 2012. Family is thus suggested as the key to change, as a force to mobilize against potentially regressive legal reforms. Themes and ideas pertaining to tradition and modernity are brought into relation here. The parents here evoke kinship as a means to stake a claim for the legitimately accepted same-sex desiring child - in law. Maternal (and fraternal) love acts here as a provocation within present politics aimed at positive queer recognition. The queer child is claimed as a valid subject for progressive modernity (and a lawful future) secured within the authenticating traditions of natal family. 
This highly stereotyped version of Indian sexuality is problematic for all sorts of reasons. To name a few: (a) the reification of cultural archetype over and above attention to actual relations, (b) the projected imaginary of the out, self-identifying same-sex sexual subject as the only viable figure for queer futurity, (c) the static cultural matrix of family life portrayed as both engendering and repressing queer sexualities. This is a familiar Foucauldian-type scenario, in which conditions of power are seen to affect the subject, emerging out of dynamics of repression. Repression in these terms becomes generative rather than suppressive or eradicating (Foucault 1990). This analysis has a particular resonance in the Indian socio-cultural scenario, where same-sex desires have so oft been described sociologically as both present and absent at the same time; recognized but disregarded (Srivastava 2004). This is why much contemporary praxis has centered on reclaimed histories (stressing same-sex desires in Indian 'cultural tradition'). Yet much work in this vein has also accented uncomfortable relations with negative repressive past attributes of governance and power in India (such as colonial laws pertaining to gender and sexuality). In these terms the past is often claimed and denounced in complex multifaceted cultural-political forms in queer praxis.

As an example of such a process we can take the case from 2015, when Padma Iyer, mother of a queer activist Harish Iyer, placed an advertisement seeking a groom for her son in the matrimonial section of the tabloid newspaper Mid Day. The advertisement read 'Seeking 2540 well settl(e)d, veg(etarian), animal loving groom, for my son Harish (Caste No Bar) (Iyer Preferred).' Iyer claimed that three major newspapers refused to carry the advertisement because it was 'illegal' (on the basis of pertaining to a same-sex relationship). Whilst several newspapers and media outlets both in India and the West have celebrated this advertisement as a significant and provocative exemplar in queer rights actions (one signified through heteronormative marriage), on closer inspection the advertisement reveals some of the complex ways in which queerness and social identity is reflected in contemporary India. The advert openly seeks a 'well placed' (read upper class) and 'Iyer preferred' (read upper caste) groom, for sanctioned matrimony in a state which still upholds IPC 377, and which criminalizes consensual non-heteronormative sex. Caste preference far from subverts tradition. The Iyer caste are Brahmins at the very top of the caste hierarchy. The imagined queer (homonormative) utopia then in this case might be read as building on the endurance of class and caste discrimination. Queer activists had heated debates on social media regarding 
this advertisement and came from both sides of the debate. Whilst some were supportive of the gesture, others were quick to admonish it.

The kind of scenario described evokes complex resonances for imagining same-sex desires and utopian politics in India. As the editors of the present volume have proposed, evocations of Indian neo-liberal futures are so often bound to the fashioning of the past as a consumable product, for instance through the neo-feudal excesses of contemporary fashion design and heritage spectacles merging with the projection of India as a contemporary superpower in various forms of public display. The past, both real and imagined, runs into the present and projected futures in intrinsic ways in Indian modernity - as ways to advertise a unique market and culture.

This same quality might be evoked in tensions pertaining to the location of queer/same-sex desiring/gender non-normative subjects within an Indian utopian ideal. Returning to the case of law, after taking consultations during 2012, the India Supreme Court ruled in 2013 that the prior 'reading down' of section 377 of the IPC 377 by the Delhi High Court in 2009 had been illegitimate and that the matter ought to have been referred to parliament. This was de-facto taken and reported internationally as a re-criminalization of homosexuality by the India judiciary, although in practice the scenario is more complex. IPC 377 might represent a criminalization of homosexuality but in a manner that outlaws sex against the order of nature as opposed to making explicit reference to homosexuality per se. Moreover, for the great majority of gender non-normative and same-sex desiring and practicing subjects in India, everyday discrimination and social inequity takes place with little recourse to law. This may be especially so for those who are most disenfranchised, perhaps from working class, and/or non-urban backgrounds, and who might lack political, social and economic capital (Dutta 2012). In these terms the queer social movements that have galvanized around and against IPC 377 may not connect well to the needs of many, who might feel alienated and excluded by the tropes of identity with which cosmopolitan queer social movements. In these terms peri-urban, non-cosmopolitan queer subjects might have felt themselves as located outside of Indian project queer modernities - as subjects whose life-worlds do not represent a suitable modernity (Boyce, 2007; Boyce, 2013, Dutta, 2012). Jasbir Puar's (2007) concept of homonationalism has been influential in arguing how nations and societies where non heterosexuals have been traditionally configured as 'criminals' and perverts have in more 
recent times included into its fold queer citizens as worthy of protection and legal recognition. But more insidiously, as she argues, this inclusion process is selective and in turn reinforces new forms of social divisions.

Within prevailing narratives, peri-urban/rural queer life-worlds may be represented as hard to reconcile with utopian queer imaginaries, in India. Such life-worlds might most often be analytically or politically located within imaginaries of repressive community and family; this being linked to the social pressure and psycho-dramas that militate against the realization of full, modern, self-identifying sexual subjectivities. This is a prevailing narrative within imaginaries of queer lives in small towns, as sites that need to be left in order for fully realized sensibilities to take shape.

This kind of imaginary of queer life-worlds as realizable elsewhere has been intrinsic to queer utopian imaginaries. For example, several of the stories from a recent anthology, Out: Stories from the New Queer India (Hajratwala, 2012) dealt with issues of queer migration to bigger cities and foreign countries but also about its failure and returning home. Angela Jones (2013) has reminded us that queer utopias might emerge in sites that resist normative regulation. Jones links utopia to aspirational ideals. She argues that utopia is a spatial feelingspace with room to breathe. Citing Sarah Ahmed's evocation of happiness and 'our' compulsive need to find happiness, Jones (2013:2) proposes that queer futurity is not 'just about crafting prescriptions for a utopian society... but making life more bearable in the present, because in doing so we create the potential for a better future.' Jones recalls Ahmed's reading of the word aspiration to remind us of the word's etiology - associated not only with projects aimed for a future better life, but with breathing - in spaces that allow room for air (and by association in this case queer recognition). Our interlocutors also evoke what Ahmed (2010:121) calls the 'melancholic migrant', one who does not let go of their racist suffering and the pressure that queers immigrants face in 'forgetting' the racism of their surrounding to comply with the happiness of the queer scene. Ahmed identifies that the legal rights and recognition given by the State to queer citizens often act to obliterate and disguise the class and labor struggle of diverse queer worlds which do not conform to the projected queer utopia - and its often cosmopolitan locations.

Queer lives in South Asia evoke complex ideals of what futurity and utopia look like. The 
cultural matrix of Indian same sex lives is linked explicitly to the idea of the repressive family and society and a resolution always points to the utopia being elsewhere. However, as our ethnography shows, the queer subject in India emerges beyond this projected reality and in several ways questions and disrupts queer neoliberal progress. Utopia in this context can then be thought of as hope as well as discontent. Hope indeed is an intrinsic quality of utopian imaginaries, of realizations that will be achieved elsewhere. While projecting new futures Aveek, Naveen and Sagar are also rejecting other ideas of futurity altogether. Queer utopia suggests hope for a better future, one that need not be dictated by Indian neoliberal policies. The potentiality of the future that emerges from peri-urban India gives an insight into the quotidian ways in which queer utopic visions are created.

The relationship between modernity, queer desires and the Indian state is marked primarily through the fight for securing sexual rights which posit the queer subjects as a project of Indian modernity, one who is capable to forge love and free to live according to one's choice. Our ethnography suggests that a feeling of failure also haunts the formation of queer subjects in India. In a neoliberal Indian state that engineers success for a few, failure and 'queer failure' to borrow Halberstam's (2011: 88) term becomes a location for resisting, dismissing and refusal to conform. Failure can be counted as a positional tool, 'the weapon of the weak' and as a form of critique. Queer utopia is an assemblage of experiential realities of failure and discontent but also the potential to resist neoliberal queer subjecthood.

\section{References}

Ahmed, Sara. 2010. The Promise of Happiness. Ann Arbor: Duke University Press.

Banerjea, Niharika. Brown, Kath. Bakshi, Leela. and Ghosh, Subhagata. 2016. 'Writing through Activisms and Academia: Challenges and Possibilities' in G. Brown and K. Browne (Eds.). The Routledge Research Companion to Geographies of Sex and Sexualities. London: Routledge.

Barton, Bernadette. 2013. Pray the Gay Away New York: New York University Press.

Beaumont, M. 2010. Reinterpreting Oscar Wilde's Concept of Utopia: The Soul of Man Under Socialism. The Soul of Man: Oscar Wilde and Socialism - and 'OSCHOLARS' $\quad$ Special $\quad$ Issues $\quad-\quad$ Spring http://www.oscholars.com/TO/Specials/Soul/Soul-Beaumont.htm 
Bloch, Ernst. 1986. The Principle of Hope, 3 vols. Trans. Neville Plaice, Stephen Plaice and Paul Knight. Cambridge, MA: MIT Press.

Boyce, Paul. 2007. '(Dis)locating men who have sex with men in Calcutta: subject, space and perception'. In Bose, B. and Bhattacharyya, S. (Eds.) The phobic and the erotic: the politics of sexualities in contemporary India, 399-416, Kolkata: Seagull Books.

Boyce, Paul. 2013. "The Object of Attention: Same-Sex Sexualities in Small-Town India and the Contemporary Sexual Subject.” In Sexuality Studies, edited by S. Srivastava, 183202. Delhi: Oxford University Press.

Califia, Pat. 1994. Public Sex: The Culture of Radical Sex. California: Cleis Press.

Dasgupta, Rohit K. 2014. 'Parties, advocacy and activism: interrogating community and Class in digital queer India. In, Pullen, C. (eds.) Queer Youth and Media Cultures., 265-277, Basingstoke: Palgrave Macmillan.

Dasgupta Rohit, K. 2015. 'Articulating dissident citizenship, belonging, and queerness on cyberspace.' South Asian Review, 35(3): 203-223

Dasgupta, Rohit, K. Forthcoming. Digital Queer Cultures of India: Politics, Intimacies and Belonging. London: Routledge

Dutta, Aniruddha. 2010. "An Epistemology of Collusion: Hijras, Kothis and the Historical (Dis) continuity of Gender/Sexual Identities in Eastern India." Gender \& History Special Issue: Gender History Across Epistemologies 24(3): 825-849.

Eagleton, Terry. 2011. Why Marx Was Right? New Haven: Yale University Press.

Edelman, Lee. 2004. No Future: Queer Theory and the Death Drive. Ann Arbor. Duke University Press.

Engebretsen, Elizabeth, L. 2012. 'On Urban Anthropology in Contemporary China.' In, Pardo, I and Prato G. (Eds.). Anthropology in the City: Methodology and Theory., 191-213, London: Routledge.

Foucault, Michel. 1990. The History of Sexuality Vol. 1. Vintage Books.

Halberstam, Judith Jack. 2011. The Queer Art of Failure. Durham: Duke University Press. Jones, Angela. 2013. A Critical Enquiry into Queer Utopias. London: Palgrave Macmillan. Manalansan, Martin. 2003. Global Divas: Filipino Gay Men in the Diaspora. Ann Arbor. Duke University Press

Munoz, Jose. 2009. Cruising Utopia: The Then and There of Queer Futurity. New York. New York University Press.

Nagar, Ila and Dasgupta, Debanuj. 2015. 'Public Koti and Private Love: Section 377, 
Religion, Perversity and Lived Desire.' Contemporary South Asia 23(4): 426-441.

Nandy, Ashish. 2009. The Intimate Enemy: The Loss and Recovery of Self Under Colonialism. New Delhi. Oxford University Press India.

Narrain, Arivind and Gupta Alok. 2011. eds. Law Like Love: Queer Perspectives on Law.

Delhi. Yoda Press.

Osella, Caroline and Osella, Filippo. 2006. Men and Masculinities in South Asia. London. Anthem Press.

Puar, Jasbir. 2007. Terrorist Assemblages: Homonationalism in Queer Times. Ann Arbor. Duke University Press.

Shahani, Parmesh. 2008. GayBombay: Globalisation, Love and Belonging in Contemporary India. New Delhi: Sage.

Sinha, Mrinalini. 1995. Colonial Masculinity: The 'manly Englishman' and The' Effeminate Bengali' in the Late Nineteenth Century. Manchester. Manchester University Press.

Srivastava, Sanjay. 2004. Introduction: Semen, History, Desire and Theory. In Sanjay Srivastava Ed. Sexual Sites, Seminal Attitudes: Sexualities, Masculinities and Culture in South Asia. New Delhi: Sage Publications.

Thelen, Tatjana. Vetters, Larissa and Beckmann, Keebet von. 2014. 'Introduction to Stategraphy: Towards a Relational Anthropology of the State. Social Analysis. 58(3): $1-19$.

Weston, Kath. 1995. Get Thee to a Big City: Sexual Imaginary and the Great Gay Migration. GLQ: A Journal of Lesbian and Gay Studies 2(3): 253-77. 